\title{
A CoMparison of Fire Regimes ANd StAND DYNAMICS IN WhITEBARK PINE (PINUS ALBICAULIS) COMMUNITIES IN THE GREATER YELLOWSTONE ECOSYSTEM
}

\author{
WILLIAM H. ROMME $\uparrow$ JAMES R. WALSH \\ DEPARTMENT OF FOREST RANGELAND AND WATERSHED STEWARDSHIP \\ COLORADO STATE UNIVERSITY $\uparrow$ FORT COLLINS
}

\begin{abstract}
$\downarrow \quad$ INTRODUCTION
Whitebark pine (Pinus albicaulis) is a keystone species of upper subalpine ecosystems (Tomback et al. 2001), and is especially important in the high-elevation ecosystems of the northern Rocky Mountains (Arno and Hoff 1989). Its seeds are an essential food source for the endangered grizzly bear (Ursus arctos horribilis), particularly in the autumn, prior to winter denning (Mattson and Jonkel 1990, Mattson and Reinhart 1990, Mattson et al. 1992). In the Greater Yellowstone Ecosystem (GYE), biologists have concluded that the fate of grizzlies is intrinsically linked to the health of the whitebark pine communities found in and around Yellowstone National Park (YNP) (Mattson and Merrill 2002). Over the past century, however, whitebark pine has severely declined throughout much of its range as a result of an introduced fungus, white pine blister rust (Cronartium ribicola) (Hoff and H agle 1990, S mith and Hoffman 2000, McDonald and Hoff 2001), native pine beetle (Dendroctonus ponderosae) infestations (Bartos and Gibson 1990, Kendall and Keane 2001), and, perhaps in some locations, successional replacement related to fire exclusion and fire suppression (Arno 2001).
\end{abstract}

The most common historical whitebark pine fire regimes are "stand-replacement", and "mixedseverity" regimes (Morgan et al. 1994, Arno 2000, Arno and Allison-Bunnell 2002). In the GYE, mixed- severity fire regimes have been documented in whitebark pine forests in the Shoshone National forest NW of Cody, WY (Morgan and Bunting 1990), and in NE Yellowstone National Park (Barrett 1994). In Western Montana and Idaho, mixed fire regimes have been documented in whitebark pine communities in the Bob Marshall Wilderness (Keane et al. 1994), Selway-Bitterroot Wilderness (Brown et al. 1994), and the West Bighole Range (Murray et al. 1998). Mattson and Reinhart (1990) found a standreplacing fire regime on the Mount Washburn Massif, within Yellowstone National Park.

It has been proposed that, as a result of $60+$ years of fire exclusion, natural fire cycles in seral whitebark pine communities have been postponed (Arno 1986, Keane 2001, Keane and Arno 2001), and that both the frequency and spatial extent of modern fires are outside of their historic range of variability. As a result, these authors argue that structure in these stands has been altered, and forest health reduced. Restoration efforts, including the use of fire, have recently been undertaken to attempt to counteract whitebark pine decline in western Montana and Idaho (Keane and Arno 1996, 2001). While the modern era of fire suppression may have altered the fire regimes in some whitebark pine communities, it is unlikely that all communities throughout its range have declined primarily as a result of fire suppression activities. Arno (2001, p.83), has postulated that in some areas- particularly were there is an extensive, 
continuous subalpine forest, as in Yellowstone National Park- large, stand-replacing burns were probably characteristic, corresponding to a standreplacement fire regime. Previous research has documented long fire intervals in subalpine forest types in YNP (Romme and Despain 1989) and these have historically exhibited stand-replacing crown fire behavior (Romme 1982). In areas such as this, modern fire suppression will have had little influence on stand dynamics or fire intervals, and restoration would be unnecessary.

Our study examines the physical structure (basal area, density, species composition) and standage structure of whitebark pine communities throughout the Greater Yellowstone Ecosystem (GYE). In addition, this study assesses the historic fire regimes in these whitebark pine communities and evaluates the influence of surrounding forest types on fire severity and extent. These objectives are being accomplished by comparing stand structure, age structure, and fire history in several whitebark pine forest communities throughout the Greater Yellowstone Area. Although investigators have found both stand-replacing and mixed severity fire regimes in other parts of whitebark pine's range, little data currently exists to quantify the historic fire regime of whitebark pine in the GYE.

In the summer of 2003, we initiated a study of whitebark pine in the GYE in order to develop a better understanding of the historic variability of fire events and stand dynamics in these communities. The data collected during that period continues to be analyzed and will be supplemented with additional field data collected during the summer of 2004. Our study addresses two major questions: i) What were the historic fire regimes of whitebark pine communities in the Greater Yellowstone Ecosystem?; and ii) Does within-stand structure and adjacent stand structure and composition influence fire dynamics in whitebark pine stands?

\section{$\uparrow \quad$ STUdy AREAS}

Research sites for this study are located on the high, forested, subalpine mountains in the Greater Yellowstone Ecosystem. These sites are dominated by whitebark pine, although subalpine fir (Abies lasiocarpa), Englemann spruce (Picea engelmannii), and lodgepole pine (Pinus contorta) are co-dominants on many sites. The climate is cold with moist springs and relatively dry summers. A total of eight study sites will be sampled. Thus far, three stands were sampled in the summer of 2003:
- Beartooth Lake, Beartooth Mountains, Shoshone N.F., WY

- Avalanche Peak, Absaroka Range, Yellowstone National Park, WY

- Wind River Lake, Absaroka Range, Shoshone N.F.,WY

In the summer of 2004, five additional sites will be sampled:

- Atlantic Peak, Wind River Range, Shoshone N.F., WY

- Union Pass, Wind River Range, Shoshone N.F., WY

- Teton Pass, Teton Range, Bridger-Teton N.F./Caribou-Targhee N.F., WY/ID

- Sawtell Peak, Centennial Mountains, Caribou-Targhee N.F., ID

- Windy Pass, Gallatin Range, Gallatin N.F., MT

\section{$\uparrow$ Methods}

The following field methods were used during the 2003 field season, and will again be employed for sampling during the su mmer of 2004. Each study site was sampled to determine stand structure, age structure, and fire history using several techniques. The point-centered-quarter (PCQ) method (Cottam and Curtis 1956, Mueller-Dombois and Ellenberg 1974) was used to collect stand structure data. Stand-origin and age-class distribution data were collected from three tree size-classes (canopy, understory, and seedling/sapling) using the points established on the PCQ transects. The fire history for each study area is being developed using fire-scar analysis techniques, based on the collection of fire scar records from both living and dead trees and logs. Communities were sampled either "intensively" or "extensively".

Intensive sampling involves:

1) Establishing two $100 \mathrm{~m}$ transects, 50 meters apart, through a stand of interest (a 1 ha sampling area)

2) Taking Point-Centered-Quarter measurements every 10 meters to determine physical stand structure along each transect

3) At each of the points (established at $10 \mathrm{~m}$ intervals along each transect), coring the nearest tree of each species in each of three size classes to determine age structure.

4) Searching for, and opportunistically sampling, fire scars within a 500 meter radius of the plot center (located between the 50 meter marks of the two transects), 
thus searching and sampling for fire over an area of .8 square $\mathrm{km}$.

Extensive sampling was conducted using the same techniques. However, in extensive sampling sites, the age structure protocol only involves coring the nearest whitebark pine individuals in each size class at each point to examine age structure, rather than coring each species present in each size class.

During the 2003 field season, the Wind River Lake site was sampled intensively. During the summer of 2004, both the Atlantic Peak and Sawtell Peak sites will also be sampled intensively. All other sites are being sampled with the extensive protocol.

Laboratory methods used to process and analyze data collected in 2003 will also be used in 2004. Increment cores and fire-scar wedges were prepared for dating using standard techniques (Stokes and Smiley 1968, Arno and Sneck 1977). All samples were visually cross-dated (Fritts 1976) and compared with master chronologies obtained from the International Tree-Ring Data Bank. Samples that were not cross-dated with accuracy were excluded from analysis. After cross-dating, samples were examined and dates were assigned to fire scars within ring series. Positions of fire scars within the rings were also assigned to assess possible seasonality of past fires. Dates of fire scars are now being compiled into a composite fire chronology (Dieterich 1980)

The FHX2 program (Grissino-Mayer 1995) will be used to compute composite fire interval statistics for all sampling areas. To describe central tendencies in fire interval distribution, both the mean fire interval (MFI) and the Weibull Median Probability (WMPI) will be computed. Fire regime statistics will be calculated for three distinct time periods in order to compare fire interval information to periods of different human activity levels: 17801850 (pre-Euro American settlement), 1851-1920 (active settlement), 1921-present (modern fire exclusion). Because summary statistics of fire interval data are highly sensitive to these subjective time periods, fire trends will also be graphically described as the percentages of sites recording fires in individual years instead of using absolute numbers (Sherriff et al. 2001). By doing so, the bias associated with disappearing evidence of older fires as old trees die is reduced.

Synthesis and evaluation is being conducted through the assessment of processed field and laboratory data.

\section{RESULTS AND DISCUSSION}

Mixed severity fire regimes consist of individual fires that vary between nonlethal understory burning and stand-replacement burns, both spatially and temporally. If whitebark pine communities in the GYE experienced a combination of nonlethal understory burns along with standreplacing fires through time, then evidence of nonlethal understory burns of small, patchy extents should be evident in fire-scar records within whitebark pine stands, at least in some locations. Fire scars on the edges of stands or patches of trees would be insufficient evidence for a mixed-severity regime, as these fire scars may be recording fires adjacent to stands rather than within them. In contrast, multiple scarred individuals in the interior of a stand would indicate that non-lethal understory burns have occurred in these communities in the past. In addition, evidence for the alteration of this "mixed" fire regime post Euro-American settlement would be provided by a reduction in fire frequency in the treering record.

In sites sampled thus far, we have not found any evidence of a historic fire regime that has included a low-severity understory component. No trees in any of the three sites in the Beartooth or Absaroka Mountains have had multiple fire scars. Several whitebark pines have been found with single scars, but there origins can not be confirmed as fireinduced. Scarring can be caused by a number of agents in the GYE including fire, diseases such as butt and root rots, insects such as mountain pine beetle, mechanical disturbance such as tree-fall, and animal damage, i.e., bear scars. Determining the cause of single scars on individual trees has been problematic. As a result, we have developed a key to aid in the selection of scarred trees to sample during the 2004 field season. This key includes a checklist of scar features, such as size and shape of scar, presence/absence of bark on scar face, multiple scars, etc., to ensure that scars that are sampled have a high likelihood of being caused by fire. Without this precaution, scars not caused by fire may be sampled, and erroneously used to calculate fire statistics for the stand.

The most convincing fire scars that we found on whitebark pine occurred at the edges of stands, adjacent to subalpine meadows. These too, were individuals bearing single scars. Due to the fact that nearby trees within the stand did not show signs of scarring, these scars may be recording fires that occurred primarily in the meadow, rather than in the forest stand. Attempts will be made in the 2004 field 
season to verify if whitebark pine stands elsewhere in the GYE tend to record adjacent meadow fires without fire spreading throughout the whitebark pine communities of interest.

We hypothesized that whitebark pine communities surrounded by an extensive, continuous subalpine forest composed of spruce/fir and lodgepole pine are characterized by infrequent, highintensity crown fires which control stand structure in both the whitebark pine community and the surrounding subalpine forest. Thus far, our sampling has been conducted in these types of extensive, subalpine forest. The lack of evidence for lowseverity fires occurring in these sites tends to support our idea that infrequent, stand-replacing fires are the dominant fire type. The age data that has been collected also supports this hypothesis. The stands sampled thus far have whitebark pine canopy trees that often exceed 350 years of age, with canopy spruce trees that are slightly younger. The average age of canopy whitebark pines across the three sites sampled in 2003 is 307 years. The Wind River Lake site was sampled intensively to compare age structure between species in three size classes (Table 1).

$\begin{aligned} & \text { Table 1. A Comparison of Mean Tree Ages (in years) for } \\
& \text { Wind River Lake intensive sampling site }\end{aligned}$
\begin{tabular}{|l|l|l|l|}
\hline \hline & $\begin{array}{l}\text { Whitebark } \\
\text { pine }\end{array}$ & $\begin{array}{l}\text { Engelmann } \\
\text { spruce }\end{array}$ & $\begin{array}{l}\text { Subalpine } \\
\text { fir }\end{array}$ \\
\hline Canopy & 273.1 & 212.8 & 147.2 \\
\hline Understory & 224.7 & 125.6 & 114.9 \\
\hline Sapling & 45.2 & 63.8 & 59.6 \\
\hline
\end{tabular}

* Size classes are defined for the purpose of this study as:

a) canopy: dominant trees, at least $2 / 3$ the height of tallest tree in stand;

b) understory: those trees that could exploit a canopy gap or become dominant with the demise of canopy individuals, $1 / 3$ to $2 / 3$ of canopy tree height; and

c) "sapling": younger trees (perhaps), those that are smaller than $1 / 3$ of canopy height but greater than $6 \mathrm{~mm}$ in diameter.

Our second hypothesis concerns whitebark pine communities not surrounded by a dense subalpine forest, but rather found in close proximity to more frequently burned Douglas-fir forests, shrublands, or grasslands. In communities such as these, we expect that the historical fire regime was dominated by burns of varying frequency and severity, often having small extents. Communities in this type of landscape context, such as in the Wind River Mountains of Wyoming, and the Centennial Mountains of Idaho will be sampled in the 2004 field season. Here, we may find evidence more characteristic of a mixed-severity fire regime.
Our data collected in 2003 indicate that in at least some locations in the GYE, whitebark pine communities found in a matrix of dense, subalpine forest have little evidence of mixed fire regimes, and that current stand structure may be the result of infrequent, stand replacing fire events coupled with subsequent nutcracker seed caching. Additional sampling in 2004 will examine a greater variety of landscape contexts in which whitebark pine occurs in the GYE, and may reveal additional variability in historical fire regimes in these communities.

\section{$\uparrow \quad$ Literature Cited}

Arno, S. F. 1986. Whitebark Pine Cone Crops: A Diminishing Source of Wildlife Food. Western Journal of Applied Forestry 1:9294.

Arno, S. F. 2000. Fire in Western Ecosystems (Ch. 5). in J. K. Brown and J. K. Smith, editors. Wildland Fire in Ecosystems: Effects of Fire on Flora. USDA Forest Service, General Technical Report RMRS-GTR-42-volume 2.

Arno, S. F. 2001. Community Types and Natural Disturbance Processes. Pages 74-88 in D. F. Tomback, S. F. Arno, and R. E. Keane, editors. Whitebark Pine Communities: Ecology and Restoration. Island Press, Washington, D.C.

Arno, S. F., and S. Allison-Bunnell. 2002. Flames in Our Forest: Disaster or Renewal? Island Press, Washington, D.C.

Arno, S. F., and R. J. Hoff. 1989. Silvics of Whitebark Pine (Pinus albicaulis). USDA Forest Service, General Technical Report INT-253.

Arno, S. F., and K. M. Sneck. 1977. A method for determining fire history in coniferous forests of the mountain west, General Technical Report INT-42. USDA Forest Service Intermountain Forest and Range Experiment Station, Ogden, Utah.

\section{CONCLUSIONS}


Barrett, S. W. 1994. Fire Regimes on Andesitic Mountain Terrain in Northeastern Yellowstone-National-Park, Wyoming. International Journal of Wildland Fire 4:6576.

Bartos, D. L., and K. E. Gibson. 1990. Insects of Whitebark Pine with Emphasis on Mountain Pine Beetle. Pages 171-178 in W. C. Schmidt and K. J. McDonald, editors. Proceedings - Symposium on Whitebark Pine Ecosystems: Ecology and Management of a High Mountain Resource. USDA Forest Service, General Technical Report, INT207.

Brown, J. K., S. F. Arno, S. W. Barrett, and J. P. Menakis. 1994. Comparing the Prescribed Natural Fire Program with Presettlement Fires in the Selway-Bitterroot Wilderness. International Journal of Wildland Fire 4:157-168.

Cottam, G., and J. T. Curtis. 1956. The Use of Distance Measures in Pytosociological Sampling. Ecology 37:451-460.

Dieterich, J. H. 1980. The Composite Fire Interval- a tool for more accurate interpretations of fire history. Pages 8-14 in J. H. Dieterich, editor. Proceedings of the Fire History Workshop, October 20-24, 1980, Tucson, Arizona. USDA Forest Service, Gen. Tech. Rep. RM81.

Fritts, H. C. 1976. Tree rings and climate. Academic Press, New York.

Grissino-Mayer, H. D. 1995. Tree-ring Reconstructions of Climate and Fire History at El Malpais National Monument, New Mexico. Ph. D. Thesis. Department of Geosciences, University of Arizona, Tucson, Arizona.

Hoff, R., and S. Hagle. 1990. Diseases of Whitebark Pine with S pecial E mphasis on White $\mathrm{P}$ ine Blister Rust. Pages 179-190 in W. C. Schmidt and K. J. McDonald, editors. Proceedings - Symposium on Whitebark Pine Ecosystems: Ecology and Management of a High Mountain Resource. USDA Forest Service, General Technical Report, INT207.
Keane, R. E. 2001. Can the Fire-dependent Whitebark Pine Be Saved? Fire Management Today 61:17-20.

Keane, R. E., and S. F. Arno. 1996. Whitebark Pine Ecosystem Restoration in Montana. Pages 51-53 in C. C. Hardy and S. F. Arno, editors. The Use of Fire in Forest Restoration. Gen Tech Rep INT-GTR-341. USDA Forest Service, Intermountain Research Station, Ogden, UT.

Keane, R. E., and S. F. Arno. 2001. Restoration Concepts and Techniques. Pages 367-401 in D. F. Tomback, S. F. Amo, and R. E. Keane, editors. Whitebark Pine Communities: Ecology and Restoration. Island Press, Washington, D.C.

Keane, R. E., P. Morgan, and J. P. Menakis. 1994. Landscape Assessment of the Decline of Whitebark-Pine (Pinus- Albicaulis) in the Bob Marshall Wilderness Complex, Montana, USA. Northwest S cience 68:213. 229.

Kendall, K. C., and R. E. Keane. 2001. Whitebark Pine Decline: Infection, Mortality, and Population Trends. Pages 221-242 in D. F. Tomback, S. F. Amo, and R. E. Keane, editors. Whitebark Pine Communities: Ecology and Restoration. Island Press, Washington, D.C.

Mattson, D. J., B. M. Blanchard, and R. R. Knight. 1992. Yellowstone Grizzly Bear Mortality, Human Habituation, and Whitebark-Pine Seed Crops. Journal of Wildlife Management 56:432-442.

Mattson, D. J., and C. Jonkel. 1990. Stone Pines and Bears. Pages 223-236 in W. C. Schmidt and K. J. McDonald, editors. Proceedings Symposium on Whitebark Pine Ecosystems: Ecology and Management of a High Mountain Resource. USDA Forest Service, General Technical Report, INT-207.

Mattson, D. J., and T. Merrill. 2002. Extirpations of grizzly bears in the contiguous United States, 1850-2000. Conservation Biology $16: 1123-1136$ 
Mattson, D. J., and D. P. Reinhart. 1990. Whitebark Pine on the Mount Washburn Massif, Yellowstone National Park. Pages 106-117 in W. C. Schmidt and K. J. McDonald, editors. Proceedings - Symposium on Whitebark Pine Ecosystems: Ecology and Management of a High Mountain Resource. USDA Forest Service, General Technical Report, INT-207.

McDonald, G. I., and R. J. Hoff. 2001. Blister Rust: An Introduced Plague. Pages 193-220 in D. F. Tomback, S. F. Arno, and R. E. Keane, editors. Whitebark Pine Communities: Ecology and Restoration. Island Press, Washington, D.C.

Morgan, P., and S. C. Bunting. 1990. Fire Effects in Whitebark Pine Forests. Pages 166-170 in W. C. Schmidt and K. J. McDonald, editors. Proceedings - Symposium on Whitebark Pine Ecosystems: Ecology and Management of a High Mountain Resource. USDA Forest Service, General Technical Report, INT207.

Morgan, P., S. C. Bunting, R. E. Keane, and S. F. Arno. 1994. Fire Ecology of whitebark pine (Pinus albicaulis) forests in the Rocky Mountains, USA. Pages $136-142$ in W. C. Schmidt and F. Holtmeier, editors. Proceedings- International Workshop on Subalpine Stone Pines and Their Environment: the Status of Our Knowledge. General Technical Report INT-GTR-309. USDA Forest Service, Intermountain Research Station, Ogden, UT.

Mueller-Dombois, D., and H. Ellenberg. 1974. Aims and Methods of Vegetation Ecology. John Wiley \& Sons, New York.
Murray, M. P., S. C. Bunting, and P. Morgan. 1998. Fire history of an isolated subalpine mountain range of the Intermountain Region, United States. Journal of Biogeography 25:1071-1080.

Romme, W. H. 1982. Fire and L andscape Diversity in Subalpine Forests of YellowstoneNational-Park. Ecological Monographs 52:199-221.

Romme, W. H., and D. G. Despain. 1989. HistoricalPerspective on the Yellowstone Fires of 1988. Bioscience 39:695-699.

Sherriff, R. L., T. T. Veblen, and J. S. Sibold. 2001. Fire history in high elevation subalpine forests in the Colorado Front Range. Ecoscience 8:369-380.

Smith, J. P., and J. T. Hoffman. 2000. Status of white pine blister rust in the Intermountain West. Western North American Naturalist 60:165179.

Stokes, M. A., and T. L. Smiley. 1968. An Introduction to Tree-ring Dating. University of Chicago Press, Chicago, IL.

Tomback, D. F., S. F. Arno, and R. E. Keane. 2001. The Compelling Case for Management Intervention. Pages 3-28 in D. F. Tomback, S. F. Arno, and R. E. Keane, editors. Whitebark Pine Communities: Ecology and Restoration. Island Press, Washington, D.C. 